\title{
Efektivitas Komunikasi Guru terhadap Motivasi Belajar Anak Usia Dini
}

\author{
Khairun Nisa ${ }^{\varpi_{1}}$, Sujarwo ${ }^{2}$ \\ Pendidikan Luar Sekolah, Universitas Negeri Yogyakarta \\ DOI: $10.31004 /$ obsesi.v5i1.534
}

\begin{abstract}
Abstrak
Komunikasi merupakan hal yang sangat penting dalam kegiatan belajar mengajar. Beberapa peserta didik di PAUD PKBM Mentari mengalami permasalahan dalam belajar yang berakibat pada prestasi belajar mereka yang semakin menurun. Penelitian ini bertujuan mendeskripsikan pengaruh efektivitas komunikasi guru terhadap motivasi belajar anak usia dini di PAUD PKBM Mentari Kayaarta, Klaten, Jawa Tengah. Metode yang digunakan adalah deskriptif kuantitaif, sampel berjumlah 30 orang warga belajar PAUD PKBM Mentari, pengumpulan data menggunakan angket. Teknik analisis data menggunakan regresi linier sederhana dengan uji $\mathrm{t}$. Hasil penelitian menunjukkan $\hat{Y}=1,36+0,99 \mathrm{X}$. Hasil uji hipotesis dengan uji $\mathrm{t}$ diperoleh nilai $\boldsymbol{t}_{\text {hitung }}>\boldsymbol{t}_{\text {tabel }}$ yaitu 12,935 $>1,697$. Artinya Efektivitas komunikasi tutor berdampak terhadap Motivasi Belajar anak usia dini di PAUD PKBM Mentari Kayaarta. Hasil temuan dalam penelitian ini menunjukkan bahwa Semakin efektif komunikasi tutor kepada anak usia dini, semakin meningkat motivasi mereka untuk mengikuti semua proses pembelajaran.
\end{abstract}

Kata Kunci: efektivitas; komunikasi tutor; motivasi belajar

\begin{abstract}
Communication is very important in teaching and learning activities. Some students in Mentari PKBM PAUD experience problems in learning that result in their learning achievement is declining. This study aims to describe the effect of the effectiveness of teacher communication on early childhood learning motivation in PKBM PAUD Mentari Kayaarta, Klaten, Central Java. The method used is descriptive quantitative, a sample of 30 people learning PAUD PKBM Mentari, collecting data using a questionnaire. Data analysis techniques using simple linear regression with $t$ test. The results showed penelitian $=1.36+$ $0.99 X$. Hypothesis test results with the $t$ test obtained value $t_{-}$(count) $>t_{-}$table is $12,935>$ 1,697. This means that the effectiveness of tutor communication has an impact on early childhood Learning Motivation in Mentari Kayaarta PKBM PAUD. The findings in this study indicate that the more effective the tutor's communication is to early childhood, the greater their motivation to participate in all learning processes.
\end{abstract}

Keywords: efektivitas; teacher communication; motivation to learn.

Copyright (c) 2020 Khairun Nisa, Sujarwo

$\triangle$ Corresponding author:

Email Address : khairunnisa.2018@student.uny.ac.id ( Jl.Colombo No.1, Karang Malang, Depok,

Sleman, Yogyakarta)

Received 11 May 2020, Accepted 29 may 2020, Published 30 May 2020 


\section{PENDAHULUAN}

Penyelenggaraan pendidikan nonformal diatur dalam pasal 26 UU No. 20 Tahun 2003 tentang sistem pendidikan Nasional dan juga pasal 100 ayat 1 peraturan pemerintahan nomor 17 tahun 2010 tentang pengelolaan dan penyelenggaraan pendidikan. Hasil dari pendidikan nonformal dapat dihargai setara dengan hasil program pendidikan formal melalui proses penilaian penyetaraan oleh lembaga yang ditunjuk oleh pemerintah daerah dengan mengacu pada standar nasional pendidikan. Menurut UU No.20 tahun 2003 tentang pendidikan Nasional, pasal 3, tujuan pendidikan pendidikan adalah mengembangkan potensi peserta didik agar menjadi manusia yang beriman dan bertaqwa kepada Tuhan Yang Maha Esa, berahlak mulia, sehat, berilmu, cakap, kreatif, mandiri dan menjadi warga yang demokratis serta bertanggung jawab (Hermawan \& Kintamani, 2015).

Manusia lahir ke dunia sudah membawa bekal kehidupan yang belum terasah atau belum teruji tanpa adanya pembelajaran atau pelatihan, bekal kehidupan itu adalah kemampuan otak manusia. Otak manusia memiliki berjuta neutron-neutron yang terus tumbuh dan mati seiring manusia lahir ke dunia dan kemampuan berpikir manusia tidaklah langsung menjadi pintar, cerdas tanpa adanya pembelajaran yang diiringi oleh motivasi.

Usia dini dikatakan sebagai golden age, yang artinya masa keemasan. Usia dini merupakan usia yang berada dalam proses pertumbuhan dan perkembangan yang pesat, pada masa ini mereka memiliki fase kehidupan yang berbeda dengan masa anak-anak maupun orang dewasa. disamping itu mereka juga memiliki ingatan yang luar biasa. sehingga mereka sangat peka terhadap segala yang terjadi di lingkungan sekitarnya. Keingin tahuan anak yang sangat besar mendorong mereka menjadi anak yang selalu ingin mencoba hal-hal baru dan anak belajar memahami segala sesuatu disekitarnya dengan mengaktifkan kelima pancainderanya termasuk telinga/pendengaran yang dapat mereka tangkap lewat komunikasi dan kemudian menghasilkan pemahaman terhadap anak usia dini tersebut. (Uce, L. 2017)

Komunikasi adalah sebuah proses pengoperan lambang dari sumber kepada penerimanya. Suatu proses dapat dibangun oleh orang yang ingin mendekatkan diri dengan personalnya. Dasarnya yaitu untuk memberi arti yang sama terhadap lambang yang disampaikan, minimal agar orang tahu, orang bersedia menerima kearah yang lebih baik. Dengan adanya penyampaian maka tersalurlah motivasi warga belajar untuk melakukan segala aktifitasnya. Keefektifan komunikasi sangatlah berpengaruh dengan motivasi belajar karena dengan adanya komunikasi yang efektif maka terlahirlah kenyamanan antar sesama lawan. Komunikasi yang dikatakan efektif adalah: (1) Keterbukaan (openess), yaitu kemauan menanggapi dengan senang hati informasi yang diterima di dalam menghadapi hubungan antarpribadi. (2) Empati (Empathy), yaitu merasakan apa yang dirasakan orang lain. (3) Dukungan (Supportiveness), yaitu sistuasi yang terbuka untuk mendukung komunikasi berlangsung efektif. (4) Rasa positif (Positivines), seseorang harus memiliki perasaan positif terhadap dirinya, mendorong orang lain lebih aktif berpartisipasi, dan menciptakan situasi komunikasi kondusif untuk interaksi yang efektif. (5) Kesetaraan atau Kesamaan (Equality), yaitu pengakuan secara diam-diam bahwa kedua belah pihak menghargai, berguna, dan mempunyai sesuatu yang penting untuk disumbangkan.

Komunikasai untuk anak usia dini tentu berbeda dengan orang dewasa. Pada anak usia dini, pada anak usia dini komunikasi harus selalu didampingi oleh orang tua ataupun orang dewasa. Pada masa usia dini, anak mulai peka/sensitif untuk menerima berbagai rangsangan. Masa peka pada masing-masing anak juga berbeda, seiring dengan laju pertumbuhan dan perkembangan anak secara individual yang dipengaruhi oleh kematangan kecerdasan. Kematangan kecerdasan tersebut biasanya ditandai dengan kemampuan anak usia dini menyusun kata dalam berbicara. Kemampuan ini akan terus berkembang jika anak usia dini sering berkomunikasi dengan orang lain. Penelitian (Hermoyo, P. 2015) menyatakan bahwa komunikasi yang efektif pada anak usia dini syaratnya antara lain: orang tua/guru perlu memilih waktu yang tepat untuk berkomunikasi 
pada anak, bahasa yang digunakan harus bisa dimengerti oleh anak, perhatikan sikap ketika berkomunikasi, jenis kelompok dimana komunikasi akan dilaksanakan.

Motivasi merupakan dorongan dan kekuatan dalam diri seseorang untuk mencapai tujuan tertentu yang ingin dicapainya (Sukirman, 2011). Kebanyakan dari mereka termotivasi hanya karena ingin mendapat ijazah saja tetapi tidak menikmati setiap proses pembelajaran yang dilakukan oleh tutor.

Motivasi tidak hanya sekedar dorongan saja, tetapi motivasi juga dapat diartikan sebagai alasan yang mendasari sebuah perbuatan yang dilakukan oleh seseorang individu, seseorang dikatakan memiliki motivasi belajar yang tinggi dapat diartikan orang tersebut memiliki alasan yang sangat kuat untuk mencapai apa yang diinginkanya dengan mengerjakan pekerjaan yang sekarang, yaitu: (1) belajar keras bekerja terus-menerus dalam waktu yang lama, tidak pernah berhenti sebelum selesai hingga tujuan yang diharapkan tercapai. (2) Tidak mudah putus asa, berpikir maju kedepan demi mencapai tujuan yang diharapkan. (3) Menunjukan minat terhadap bermacam-macam masalah. Seperti menunjukan minat belajar, menunjukkan minat dalam pembelajaran, dan bukan hanya pada satu jenis mata pelajaran saja, tetapi berbagai macam pelajaran. (4) Lebih senang belajar mandiri untuk sejauh mana potensi atau kemampuan yang ada didalam dirinya. (5) Tidak cepat bosan pada tugas-tugas rutin hal-hal yang bersifat mekanis, berulang-ulang begitu saja, sehingga kurang kreatif) karena tidak ada hal yang baru atau menarik dan menantang untuk memicu semangat individu atau diri sendiri, (6) Dapat mempertahankan pendapatnya (kalau sudah yakin akan sesuatu) mempertahankan pendapat yang dianggapnya benar dan yakin banyak faktor atau sebab yang mendukung pendapatnya benar. (7) Tidak mudah melepaskan hal yang diyakini. Pendapat yang sudah diyakini benar tidak akan dilepas, karena memiliki semangat untuk mempertahankan keyakinannya. (8) Senang mencari dan memecahkan masalah soal-soal untuk mendapatkan inspirasi atau masukan baru maupun pengetahuan baru untuk mengetahui ilmu pengetahuannya (Nursalam \& Efendi, 2008).

Motivasi dapat menentukan baik tidaknya dalam mencapai tujuan sehingga semakin besar motivasinya akan semakin besar kesuksesan belajarnya. Sesorang yang mempunyai motivasi tinggi akan giat berusaha untuk belajar, begitu juga sebaliknya jika seseorang mempunyai motivasi yang rendah akan bersikap acuh tak acuh, mudah putus asa.

Belajar merupakan tindakan dan perilaku yang kompleks. Sebagai tindakan, maka belajar hanya dialami oleh siswa sendiri. Siswa adalah penentu terjadinya atau tidak terjadinya proses belajar (Yuniastuti, 2013). Menurut Ambarukmi \& Wijayanti (2019) belajar adalah perubahan tingkah laku dan terjadi karena hasil pengalaman. Sejalan dengan itu, Iskandar (Febrina \& Isroah, 2012) mengatakan belajar merupakan usaha yang dilakukan seseorang melalui interaksi dengan lingkungannya untuk merubah perilakunya.

Motivasi Belajar adalah dorongan dari proses belajar dan tujuan dari belajar adalah mendapatkan manfaat dari proses belajar. Beberapa siswa mengalami masalah dalam belajar yang berakibat prestasi belajar tidak sesuai dengan yang diharapkan. Untuk mengatasi masalah yang dialami tersebut perlu ditelusuri faktor yang mempengaruhi hasil belajar di antaranya adalah motivasi belajar siswa, dimana motivasi belajar merupakan syarat mutlak untuk belajar, serta sangat memberikan pengaruh besar dalam memberikan gairah atau semangat belajar (Susilo, 2013). Sedangkan menurut Clayton Aldefer (dalam Muslimah, 2015) motivasi belajar adalah kecenderungan siswa dalam melakukan segala kegiatan belajar yang didorong oleh hasrat untuk mencapai prestasi atau hasil belajar sebaik mungkin. Menurut Syah (dalam Afdilla, 2017) faktor yang mempengaruhi motivasi belajar siswa adalah: Guru, Orang tua dan keluarga, masyarakat dan lingkungan.

Salah satu untuk meyukseskan pembelajaran setelah motivasi yaitu komunikasi. Manusia didalam kehidupannya harus berkomunikasi, artinya memerlukan orang lain dan membutuhkan kelompok atau masyarakat untuk saling berinteraksi. Hal ini merupakan suatu hakekat bahwa sebagian besar manusia terbentuk dari hasil integrasi sosial dengan 
sesama dalam kelompok dan masyarakat. Komunikasi adalah suatu hal yang sangat penting dalam sebuah pembelajaran, komunikasi tidak hanya penting dalam sebuah pembelajaran karena jika melibatkan komunikasi hanya dalam pembelajaran maka hasil yang lainnya tidak maksimal. Berbicara tentang komunikasi, komunikasi adalah hal yang paling mendasar untuk melibatkan warga belajar dalam pendekatan emosional. Dengan pendekatan emosional maka warga belajar lebih mempertimbangkan hal-hal yang berkenaan dengan belajar.

Penelitian (Choiro et al., 2018) yang berjudul "keaktifan belajar peserta didik pada transfer pengetahuan kerjainan pandai besi"menyatakan bahwa interaksi atau komunikasi merupakan ciri utama dari kegiatan pembelajaran. Pengembangan aktivitas dan kreativitas peserta didik melalui berbagau interaksi dan pengalaman belajar adalah hakekat dari proses pembelajaran.

Sedangkan hasil penelitian Lilis Nuryanti (dalam wijananti \& Yulianti, 2010) menghasilkan temuan bahwa guru harus lebih kreatif dalam merancang dan mengembangkan perangkat pembelajaran agar mampu meningkatkan kemampuan berpikir kritis siswa sehingga menjadi habit. Guru harus melibatkan siswa dalam situasi pembelajaran yang mampu merangsang kemampuan siswa dalam berpikir kritis melalui berbagai model pembelajaran aktif. Dari penjelasan hasil penelitian tersebut dapat disimpulkan pendidik harus melibatkan peserta didik untuk aktif lewat komunikasi yang efektif.

Sedangkan penelitian (Aulina, C. N., 2018), menyatakan bahwa dalam meningkatkan motivasi belajar anak dapat digunakan dengan metode whole brain teaching, yang Kunci utamanya adalah interaksi. Interaksi baik guru sebagai pembicara dan anak sebagai pendengar harus menggunakan gerakan/gesture dengan baik. Guru menggambarkan apa yang mereka katakan dengan gerakan-gerakan bermakna dan anak mendengarkan tentang apa yang dijelaskan tersebut. Hal ini dilakukan bergantian kepada anak agar anak dapat menerapkan sebagai pembicara dan pendengar dengan baik pada temannya.

Dari hasil observasi awal yang dilakukan di PAUD PKBM Mentari Kayaarta, Klaten, tutor dan peserta didik PAUD belum mempunyai ciri-ciri sepenuhnya tentang bagaimana menjalin komunikasi yang efektif. PAUD di PKBM Mentari memiliki TPA, KB, TK, TPQ, dan Inklusi. Dari hasil wawancara kepada kepala PKBM yakni bapak Guruh Suasana Eddy dan beberapa tutor PAUD, menghasilkan informasi bahwa peserta didik kurang begitu tertarik dengan pembelajaran yang sudah dijadwalkan oleh peyelenggara, cepat bosan dengan materi-materi pembelajaran, tidak memiliki semangat untuk belajar, diakibatkan kurangnya motivasi warga belajar untuk mengikuti sebuah pembelajaran. Oleh sebab itu peneliti tertarik untuk melakukan penelitian yang dikaitkan dengan komunikasi tutor terhadap peserta didik, sehingga penelitian ini berjudul "Pengaruh Efektivitas Komunikasi Tutor Terhadap motivasi belajar anak usia dini di PAUD PKBM Mentari Kayaarta"

\section{METODOLOGI}

Populasi dalam penelitian ini adalah seluruh warga belajar PAUD TK usia 5-6 Tahun yang berada di PKBM Mentari Kayaarta. Sampel dalam penelitian ini adalah $100 \%$ dari jumlah peserta didik PAUD TK yang ada di PKBM Mentari 32 anak. Dengan cara menggunakan random sampling maka terpilihlah 30 orang peserta didik PAUD TK PKBM Mentari Kayaarta.

Jenis angket yang disebarkan kepada responden adalah angket tertutup karena hanya memiliki 4 option jawaban yang sudah disediakan oleh penulis yaitu sangat setuju dengan nilai 4, setuju nilai 3, kurang setuju nilai 2 dan tidak setuju bernilai 1 . Artinya, pada pertanyaan yang mengarah pada jawaban positif, maka bobot diberikan nilai 4. Jika pertanyaan mengarah pada jawaban negatif, maka bobot diberikan nilai 1. 
$5 \%$.

Rumus yang digunakan adalah korelasi product moment dengan taraf signifikansi

$$
r_{x y}=\frac{\mathbf{N} \sum \mathbf{x y}-\left(\sum \mathbf{x}\right)\left(\sum \mathbf{y}\right)}{\sqrt{\left\{\mathbf{N} \sum x^{2}-\left(N \sum x\right)^{2}\right\}\left\{N \sum y^{2}-\left(\sum y\right)^{2}\right\}}}
$$

Instrumen penelitian dikatakan valid jika $r_{\text {hitung }}>r_{\text {tabel }}$. Pada taraf kepercayaan $5 \%$, jika jumlah sampel 30 maka $30-2=28$. sehingga taraf signifikan yaitu 0,361 (Sugiyono, 2010) Setelah dilakukan uji validitas terhadap angket Variabel efektifitas komunikasi dan motivasi belajar dapat disimpulkan bahwa dari 20 item pernyataan dinyatakan semuanya valid.

Reabilitas menunjukkan bahwa suatu instrumen dapat dipercaya untuk digunakan sebagai alat pengumpulan data karena instrument tersebut sudah baik. Untuk menguji reabilitas angket digunakan rumus untuk mengemukakan Arikunto (2006):

$$
r_{11}=\left(\frac{\boldsymbol{k}}{(\boldsymbol{k}-\mathbf{1})}\right)\left(1-\frac{\sum \sigma b^{2}}{\sigma t^{2}}\right)
$$

Untuk mengetahui varians digunakan rumus:

$$
\sigma_{t}^{2}=\frac{\sum Y^{2}-\frac{(Y)^{2}}{n}}{n}
$$

Tingkat reliabilitas antara 0.800 tergolong sangat tinggi, 0.600 tergolong tinggi, 0.400 tergolong cukup dan $0.00 \mathrm{~s} / \mathrm{d} 0.399$ tergolong sangat rendah. Berdasarkan hasil perhitungan di atas diperoleh nilai r11 sebesar 0,810. Maka rhitung > rtab dimana atau 0,810>0,361 dengan demikian angket efektivitas komunikasi tutor dan motivasi belajar warga paket $\mathrm{C}$ PKBM Quba dianggap reliable (terandal).

Teknik analisis data menggunakan Regresi linear sederhana. Uji linear dilakukan untuk mengetahui apakah dapat pengaruh antara variabel bebas $(\mathrm{x})$ dan variabel terikat $(\mathrm{y})$ bersifat linier. Uji linieritas dilakukan melalui persamaan sebagai berikut : $y=a+b x$ ((Hardiansyah, 2019) dimana:

$$
\begin{aligned}
& \mathrm{a}=\frac{\left(\sum y\right)\left(\sum y^{2}\right)-\left(\sum x\right)\left(\sum x y\right)}{n\left(\sum x^{2}\right)-\left(\sum x\right)^{2}} \\
& \mathrm{~b}=\frac{\left(\sum x y\right)\left(\sum x\right)-\left(\sum y\right)}{n\left(\sum x^{2}\right)-\left(\sum x\right)^{2}}
\end{aligned}
$$

Linieritas dilakukan untuk mengetahui linier tidaknya pengaruh antara variabel bebas ( $\mathrm{x}$ ) dan variabel terikat (y). Untuk menentukan apakah hipotesis yang telah dirumuskan dapat diterima atau tidaknya digunakan uji " $\mathrm{t}$ " dengan rumus:

$$
\mathrm{t}=\frac{r \sqrt{n}-2}{1-r^{2}} \quad(\text { Hardiansyah, 2019) }
$$

Dengan kriteria, harga $\mathrm{t}$ hitung dibandingkan dengan harga $\mathrm{t}$ tabel. Dengan taraf signifikan $95 \%$ atau alpha $5 \%$ dan $\mathrm{dk}=(\mathrm{n}-2)$, maka apabila $t_{\text {hitung }}>t_{\text {tabel }}$ maka $H_{o}$ ditolak dan $H_{a}$ diterima.

Adapun langkah-langkah penelitian yang dilakukan adalah sebagai berikut:

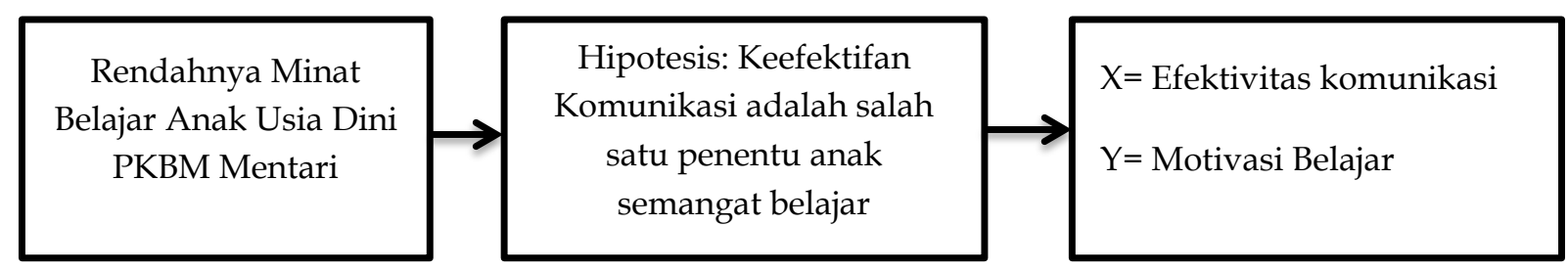

\section{Gambar langkah penelitian}




\section{HASIL DAN PEMBAHASAN}

Yayasan Mentari Kayaarta terletak di perkiosan tulung No.259, Area sawah, Tulung, Kec. Tulung, Kabupaten Klaten, Jawa Tengah. Merupakan sebuah lembaga Pusat Kegiatan Belajar Masyarakat (PKBM) dengan legalitas Akte pendirian menjalankan tugas, pokok dan fungsinya dengan pendekatan program berbasis budaya Bali yang dijiwai oleh agama Hindu dan nilai-nilai luhur yang berkembang di masyarakat.

PKBM Mentari Kayaarta dalam pelaksanaan kegiatannya berbasis pendidikan kemasyarakatan memfokuskan bidang pendidikan non formal dengan pendekatan budaya lokal. Cakupan bidang program PKBM Mentari Kayaarta salah satunya yang paling dominan dan memiliki banyak peminat adalah PAUD, yang terbagi kedalam beberapa jenis, diantaranya TPA, TK, TPQ, dan Inklusi. Penelitian ini dilakukan terhadap anak PAUD usia TK YANG BERUMUR 5-6 Tahun.

\section{Deskripsi Data Hasil Penelitian Motivasi Belajar}

Berdasarkan pengolahan data maka diperoleh hasil nilai terkecil $=49$, nilai terbesar $=$ 70 , banyak kelas $=5,7$ dibulatkan menjadi 5 , panjang kelas $=5$, rata-rata $=60,5$, varians $\left(S^{2}\right)$ $=32,30$, simpangan baku 5,68, median $=58,5$, modus $=63$. Berikut disajikan tabel frekuensi Motivasi Belajar.

Tabel 1. Distribusi Frekuensi Motivasi Belajar

\begin{tabular}{llll}
\hline No. & Nilai & $\begin{array}{l}\text { Frekuens } \\
\text { i (n) }\end{array}$ & Frekuensi (\%) \\
\hline 1 & $49-53$ & 1 & $3,33 \%$ \\
2 & $54-58$ & 11 & $36,6 \%$ \\
3 & $59-63$ & 10 & $33,3 \%$ \\
4 & $64-68$ & 6 & $20 \%$ \\
5 & $69-73$ & 2 & $6,66 \%$ \\
Jumlah & & 30 & $100 \%$ \\
\hline
\end{tabular}

Adapun histogram distribusi frekuensi Motivasi Belajar disajikan dalam tabel disajikan dalam tabel dibawah ini:

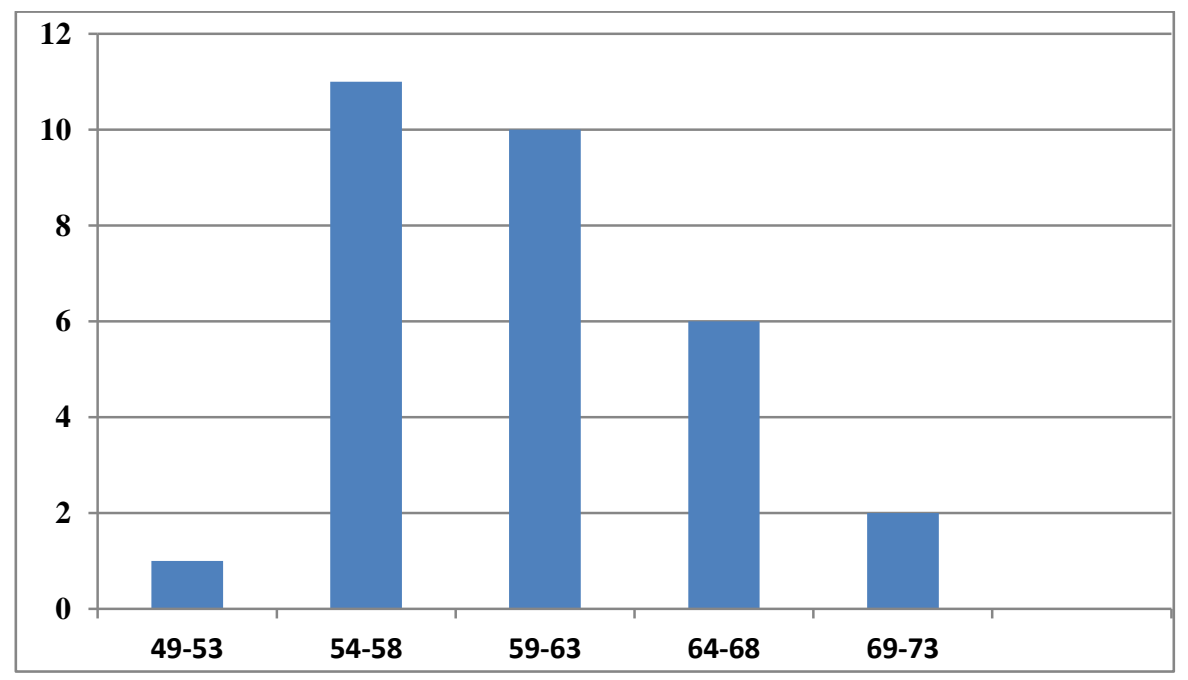

Gambar 1. Grafik Distribusi Frekuensi Motivasi Belajar

Deskripsi motivasi belajar yang dikemukakan dalam penelitian ini adalah hasil temuan dan hasil pengolahan data yang berkaitan dengan rumusan masalah tentang bagaimana motivasi belajar anak usia dini di PAUD PKBM Mentari Kayaarta. 
Tabel 2. Hasil Perhitungan Kategori Motivasi Belajar

\begin{tabular}{llllll}
\hline \multirow{2}{*}{ No. } & Aspek & \multicolumn{4}{c}{ Kategori Rata-rata } \\
\cline { 3 - 6 } & & SS & S & KS & TS \\
\hline 1 & Tekun dan Ulet & $12 \%$ & $10,25 \%$ & $6,375 \%$ & $1,125 \%$ \\
2 & Minat yang tinggi & $9,25 \%$ & $10,5 \%$ & $7,5 \%$ & $1,25 \%$ \\
3 & Mandiri & $12 \%$ & $7,5 \%$ & $8,5 \%$ & $1,5 \%$ \\
4 & Hasrat & $12,5 \%$ & $8,5 \%$ & $7 \%$ & $2 \%$ \\
\hline
\end{tabular}

Dari Tabel 2 di atas, diketahui bahwa anak usia dini di PAUD PKBM Mentari Kayaarta memiliki motivasi belajar yang cukup baik terhadap suatu pembelajaran dimana pada aspek hasrat keinginan pembelajaran yang tidak membosankan. Hal tersebut sesuai dengan isi angket yang menanyakan "saya mengikuti proses belajar mengajar dengan sungguh-sungguh" dan mereka menjawab sangat setuju. Kemudian pada aspek mandiri yang meliputi bekerja sendiri dalam mengerjakan tugas-tugas, dan memiliki sikap kreatif. Hal tersebut sesuai dengan isi angket yang menanyakan "ketika saya mengerjakan tugas saya berusaha mengerjakannya sendiri", setengah dari mereka menjawab sangat setuju.

\section{Deskripsi Data Hasil Penelitian Efektifitas Komunikasi Tutor}

Berdasarkan pengolahan data maka diperoleh hasil nilai terkecil $=49$, nilai terbesar $=$ 70 , banyak kelas $=5,7$ dibulatkan menjadi 5 , panjang kelas $=5$, rata-rata $=52,31$, varians $\left(\mathrm{S}^{2}\right)$ $=81,57$, simpangan baku 9,03, median $=57,95$, modus $=59,3$. Berikut disajikan tabel frekuensi Efektivitas komunikasi tutor.

Tabel 3. Distribusi frekuensi Efektivitas Komunikasi Tutor

\begin{tabular}{llll}
\hline No. & Nilai & Frekuensi (n) & Frekuensi (\%) \\
\hline 1. & $49-53$ & 5 & $16,66 \%$ \\
2. & $54-57$ & 7 & $23,33 \%$ \\
3. & $58-62$ & 11 & $36,66 \%$ \\
4. & $63-67$ & 4 & $13,33 \%$ \\
5. & $68-72$ & 3 & $10 \%$ \\
\hline Jumlah & & 30 & $100 \%$ \\
\hline
\end{tabular}

Adapun histogram distribusi frekuensi Efektivitas komunikasi tutor disajikan dalam tabel dibawah ini:

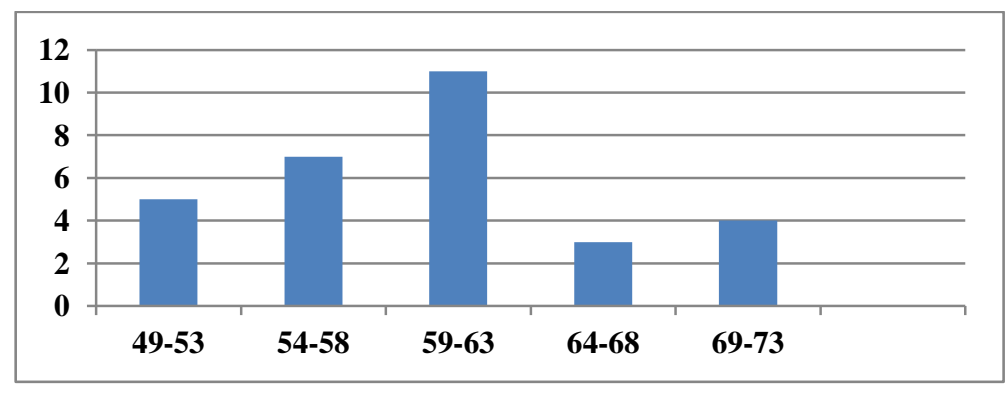

Gambar 1. Grafik Distribusi Frekuensi Komunikasi Tutor

Deskripsi pengaruh Efektivitas komunikasi tutor yang dikemukakan dalam penelitian ini adalah hasil temuan dan hasil pengolahan data yang berkaitan dengan jawaban atas pertanyaan penelitian yang telah dikemukakan pada rumusan masalah, karena masalah merupakan sesuatu yang perlu dipahami dan dicarikan jawabannya, supaya masalah dapat terjawab atau dipecahkan dengan baik maka masalah harus dirumuskan 
secara spesifik. Untuk menjawab pertanyaan penelitan bagaimana efektivitas komunikasi yang diterapkan tutor di Pkbm Quba maka dapat dilihat melalui tabel berikut, terlebih dahulu ditentukan skala sebagai tolak ukur pembinaan dalam penelitian ini dengan rumus sebagai berikut:

Tabel 4. Hasil Perhitungan Kategori Komunikasi Tutor

\begin{tabular}{ll|l|l|l|l}
\hline \multirow{2}{*}{ No. } & \multicolumn{4}{|c}{$\begin{array}{c}\text { Kategori } \\
\text { Rata-rata }\end{array}$} \\
\cline { 3 - 6 } & & SS & S & KS & TS \\
\hline 1. & Keterbukaan & $11,5 \%$ & $8 \%$ & $8,255 \%$ & $2,25 \%$ \\
2. & Empati & $12 \%$ & $7,75 \%$ & $8 \%$ & $1,25 \%$ \\
3. & Dukungan & $10,75 \%$ & $8,25 \%$ & $8 \%$ & $2,75 \%$ \\
4. & Rasa positif & $10,25 \%$ & $10,75 \%$ & $7,75 \%$ & $2,25 \%$ \\
5. & Kesamaan & $11 \%$ & $9,75 \%$ & $9,75 \%$ & $2 \%$ \\
\hline
\end{tabular}

Dari olahan data pada Tabel 4.3 diketahui bahwa rata-rata tutor hanya menerapkan kelima aspek tersebut beberapa aspek tersebut ialah keterbukaan, emphaty, dukungan, rasa positif, dan kesamaan. dimana aspek yang paling banyak diterapkan yaitu aspek emphaty.

\section{Hasil Uji Validitas}

Pelaksanaan uji coba angket tentang Efektivitas komunikasi tutor terhadap motivasi belajar paket $C$ dilaksanakan terhadap 30 yang mengikuti kesetaraan paket $C$. Berdasarkan hasil perhitungan koefisien korelasi, untuk angket efektivitas komunikasi tutor maka diperoleh koefisien korelasi validitas nomor 1 diketahui $r_{\text {hitung }}=0,361$ dengan $\mathrm{N}=30$ pada taraf signifikan $\alpha=5 \%$, maka diketahui $r_{\text {tabel }}=0,428$. Dari hasil tersebut dapat dilihat bahwa $\mathrm{r}_{\text {hitung }}$ lebih besar dari $\mathrm{r}_{\text {tabel }}(0,428>0,334)$. Berdasarkan data tersebut, dapat dicontohkan bahwa item nomor soal 1 adalah valid. Dari 20 item angket efektivitas komunikasi tutor yang disebarkan semuanya valid. Sedangkan untuk angket motivasi belajar diperoleh koefisien korelasi validitas nomor 1 diketahui $r_{\text {hitung }}=0,639$ dengan $\mathrm{N}=30$ pada taraf signifikan $\alpha=5 \%$, maka diketahui $r_{\text {tabel }}(0,639>0,361)$. Berdasarkan data tersebut, dapat dicontohkan bahwa item nomor soal 1 adalah valid. Dari 20 item soal angket tentang motivasi belajar yang disebarkan diketahui semua soal valid.

\section{Hasil Uji Reliabilitas}

Berdasarkan hasil perhitungan angket efektivitas komunikasi tutor dengan menggunakan rumus Alpha, diketahui $\mathrm{r}_{11}=0,810$ dan setelah dikonsultasikan dengan indeks korelasi termasuk dalam kategori sangat tinggi. Begitu juga dari hasil perhitungan angket motivasi belajar dengan menggunakan rumus Alpha, diketahui $r_{11}=0,800$ dan setelah dikonsultasikan dengan indeks korelasi termasuk dalam kategori tinggi. Dengan demikian dapat disimpulkan bahwa angket efektivitas komunikasi tutor dan angket motivasi belajar telah memenuhi kriteria reliabilitas sehingga dapat digunakan sebagai alat pengumpul data.

\section{Hubungan Efektivitas Komunikasi Tutor terhadap Motovasi Belajar Warga Paket C PKBM Quba}

Untuk mengetahui apakah ada hubungan efektivitas komunikasi tutor dengan motivasi belajar anak usia dini di PKBM Mentari Kayaarta dalam penelitian ini dilakukan dengan menggunakan regresi linier sederhana. Analisis digunakan untuk memprediksi nilai variabel independen mengalami kenaikkan atau penurunaan. Dari hasil perhitungan diketahui persamaan regresinya adalah $\hat{Y}=1,36+0,99 X$. Dengan memperhatikan persamaan tersebut, maka diketahui ada Hubungan efektivitas komunikasi dengan motivasi belajar 
anak usia dini di pkbm Mentari Kayaarta. Berdasarkan data pada tabel 2, dapat dilihat garis regresi dengan persamaan $\hat{Y}=1,36+0,99 X$. Jika nilai $x=58,93$ maka: $\hat{Y}=1,36+0,99(58,93)=$ 59,70

Dari persamaan regresi di atas dapat diartikan bahwa, bila variabel $\mathrm{x}$ bertambah 1 maka variabel y akan bertambah sebesar 0,99. Jadi jika pertambahan x sebesar 58,93 maka y akan bertambah sebesar 59,70. Dengan demikian dapat disimpulkan bahwa terdapat Hubungan efektivitas komunikasi tutor dengan motivasi belajar anak usia dini di PAUD PKBM Mentari Kayaarta.

Uji hipotesis dilakukan setelah diketahui terlebih dahulu hasil perhitungan besar koefisien korelasi variabel $\mathrm{X}$ terhadap $\mathrm{Y}$. Koefisien korelasi tersebut diuji signifikannya dengan uji t. Koefisien korelasi hubungan efektivitas komunikasi tutor dengan motivasi belajar anak usia dini dari hasil perhitungan diketahui ada korelasi yang positif ( $\mathrm{r}_{\text {hitung }}=$ 0,978 ) antara efektivitas komunikasi tutor $(X)$ dengan motivasi belajar anak usia dini $(Y)$, berarti semakin baik efektivitas komunikasi tutor yang dilakukan tutor semakin baik pula tingkat motivasi belajar anak usia dini di PAUD PKBM Mentari Kayaarta. Untuk mengetahui apakah efektivitas komunikasi tutor memiliki pengaruh yang signifikan terhadap motivasi belajar anak usia dini di PAUD PKBM Mentari Kayaarta. Maka dilakukan pengujian dengan rumus uji $t$ dan hasil dari perhitungan diperoleh nilai $t_{\text {hitung }}>t_{\text {tabel }}$ yaitu $12,932>1,697$ Sedangkan besarnya konstribusi efektivitas komunikasi tutor dapat dilihat melalui perhitungan determinan diperoleh nilai $\mathrm{D}=95,6 \%$, artinya bahwa meningkat atau menurunya motivasi belajar anak usia dini di PAUD Pkbm Mentari Kayaarta dipengaruhi oleh efektivitas komunikasi tutor sedangkan sisanya 4,4 \% disebabkan faktor lain yang tidak termasuk dalam analisis ini.

\section{Pembahasan}

Motivasi merupakan suatu dorongan agar seseorang melakukan sesuatu, baik dorongan internal maupun eksternal, dorongan eksternal didapatkan agar warga belajar dapat mengikuti pembelajaran yang tidak hanya monoton tentang belajar saja, tetapi mengenali sekitar dan juga pengajarnya atau yang disebut tutor. Efektivitas komunikasi tutor merupakan salah satu cara untuk membentuk karakter warga belajar dan memotivasi warga belajar. Efektivitas komunikasi terjadi apabila kesamaan persepsi antara tutor dan peserta didiknya, kesamaan dalam artian ada umpan balik antara tutor dan warga belajar, dan apabila rangsangan yang disampaikan dan dimaksudkan oleh pengirim atau sumber, berkaitan erat dengan rangsangan yang ditangkap dan dapat dipahami oleh penerima. Maka agar warga belajar dapat termotivasi dalam pembelajaran maka warga belajar butuh dorongan dari luar. Menurut Hurlock (dalam julianty, 2019)"komunikasi dapat dilakukan dalam setiap bentuk bahasa tertulis, lisan, isyarat tangan, ungkapan musik dan artistik dan sebagainya". Dari aspek komunikasi, yaitu mengerti yang dimaksud oleh orang lain dan kemampuan mengkomunikasikan pikiran dan perasaan diri sendiri kepada orang lain sehingga dapat dimengerti.

Dari uraian di atas, dapat disimpulkan bahwa komunikasi adalah interaksi manusia dengan proses penyampaian lambang-lambang seperti bahasa lisan, tertulis, maupun isyarat yang memiliki pengertian tertentu kepada orang lain. Komunikasi juga merupakan kegiatan berbagi pikiran, makna, dan pengiriman pesan sehingga orang lain dapat mengerti.selanjutnya Menurut Suprapto Tommi (dalam Gunawan, 2015) “proses komunikasi adalah setiap langkah mulai dari saat menciptakan informasi sampai dipahami oleh komunikan". Hal tersebut dimaksudkan bahwa komunikasi merupakan suatu proses, dimana kompenen-kompenen saling terkait.

Menurut Suprapto Tommi (dalam Gunawan, 2015) dalam aplikasinya, langkahlangkah dalam proses komunikasi adalah sebagai berikut: a) langkah pertama, ide/gagasan diciptakan oleh sumber/komunikator. b) Langkah kedua, ide yang diciptakan tersebut kemudian dialih bentukan menjadi lambang-lambang komunikasi yang mempunyai makna 
da dikirimkan. c) Langkah ketiga, pesan yang telah di enconding tersebut selanjutnya dikirimkan melalui saluran/media yang sesuai dengan karakteristik lambang-lambang komuniksi ditujukan kepada komunikan. d) Langkah keempat, penerima menafsirkan isi pesan sesuai dengan persepsinya untuk mengartikan maksud pesan tersebut. e) Langkah kelima, apabila pesan tersebut telah berhasil di decoding, khalayak akan mengirimkan kembali pesan tersebut ke komunikator.

Berdasarkan uraian pendapat para ahli diatas efektivitas komunikasi tutor di terhadap motivasi belajar anak usia dini di PAUD PKBM Mentari Kayaarta sudah hampir berhasil membuat warga belajar menjadi termotivasi untuk belajar. Berdasarkan dari hasil penelitian yang didapati tutor rata-rata menggunakan aspek emphaty dan dukungan. Dengan demikian dapat diartikan bahwa efektivitas komunikasi tutor di PAUD Pkbm Mentari Kayaarta dalam kategori cukup baik.

Penelitian (Choiro et al., 2018) yang berjudul "keaktifan belajar peserta didik pada transfer pengetahuan kerjainan pandai besi" menyimpulkan bahwa keaktifan peserta didik dalam proses belajar menjadi penentu keberhasilan peserta didik dalam menguasai serangkaian keterampilan yang di transfer oleh pendidik. Peserta didik dalam proses belajarnya melakukan kegiatan mengamati, mendengarkan, praktik dan tanya jawab. Sehingga dalam disimpulkan bahwa dalam proses pembelajaran pasti adanya komunikasi antara pendidik dan peserta didik, jika komunikasi pendidik kepada peserta didik baik, maka akan menghasilkan pemahaman yang baik pula pada peserta didik.

Efektivitas komunikasi tutor yang diterapkan di PAUD PKBM Mentari Kayaarta hanya beberapa saja diantaranya aspek emphaty, dukungan dan keterbukaan. Tutor menerapkan aspek emphaty yaitu mengutamakan memilih diam pada saat ada yang berbicara di dalam kelas. Kemudian tutor menerapkan dukungan yaitu mengutamakan menenangkan teman yang sedang marah-marah karena nilai ulangan yang jelek. Selanjutnya ketebukaan yaitu tutor mengutamakan tidak merahasiakan apapun dari peserta didik.

Ciri-ciri efektifitas komunikasi antar pribadi menurut Kumar (Edra, 2017) bahwa ciriciri komunikasi antarpribadi tersebut yaitu : 1) Keterbukaan (openess), yaitu kemauan menanggapi dengan senang hati informasi yang diterima di dalam menghadapi hubungan antarpribadi. 2) Empati (Empathy), yaitu merasakan apa yang dirasakan orang lain. 3) Dukungan (Supportiveness), yaitu sistuasi yang terbuka untuk mendukung komunikasi berlangsung efektif. 4) Rasa positif (Positivines), seseorang harus memiliki perasaan positif terhadap dirinya, mendorong orang lain lebih aktif berpartisipasi, dan menciptakan situasi komunikasi kondusif untuk interaksi yang efektif. 5) Kesetaraan atau Kesamaan (Equality), yaitu pengakuan secara diam-diam bahwa kedua belah pihak menghargai, berguna, dan mempunyai sesuatu yang penting untuk disumbangkan.

Dengan demikian efektivitas komunikasi tutor sangat berpengaruh terhadap motivasi warga belajar. Setiap warga belajar biasanya mempunyai prinsip atau pola pikir yang berbeda-beda, maka tutor harus dapat memahami hal itu dikarenakan tidak hanya seusia. yang berada di PAUD tersebut, tetapi ada beraneka ragam usianya. Untuk itu diperlukan proses komunikasi, Proses komunikasi dimulai dari ide/gagasan dari komunikator, membentuk lambang-lambang komunikasi yang bermakna, pesan yang telah utuh lalu dikirimkan, komunikan menafsirkan sendiri sesuai dengan persepsinya, hingga komunikan memberikan umpan balik atau feedback kepada komunikator sebagai tanda bahwa proses komunikasi berjalan dengan terjadinya saling memahami antara komunikator dengan komunikan.

Temuan lapangan lainya yang mengungkapkan motivasi belajar dibuktikan melalui metode penelitian dengan teknik pengumpulan data menggunakan angket mengenai motivasi belajar anak usia dini di PAUD PKBM Mentari Kayaarta, berdasarkan hasil pengolahan data motivasi belajar di daerah tersebut masih tergolong cukup baik. Dimana pada penilaian 4 aspek yaitu tekun dan ulet, minat yang tinggi, mandiri, dan hasrat. Tetapi hal tersebut masih kecil kemungkinannya karena keluarga dan lembaga Pkbm masih mau 
menjelaskan pentingnya motivasi. Dengan demikian dapat diartikan bahwa motivasi belajar anak usia dini di PKBM Mentari Kayaarta berada dalam kategori cukup baik. Berdasarkan hasil temuan peneliti yang didapatkan peneliti dilapangan selanjutnya dilakukan perhitungan menggunakan korelasi, diperoleh koefisien korelasi $r_{x y}=0,978$. Hal ini mengandung arti bahwa efektivitas komunikasi tutor memiliki korelasi terhadap motivasi belajar. Sedangkan koefisien determinasi dapat diketahui pengaruh efektivitas komunikasi tutor terhadap motivasi belajar sebesar $95,6 \%$ dan sisa nya $4,4 \%$ variabel-variabel lain yang turut mendukung motivasi belajar anak usia dini di PKBM Mentari Kayaarta, namun tidak diteliti oleh penulis.

Untuk menguji keberartian koefisien korelasi diperoleh dengan menggunakan uji $\mathrm{t}$ hasil dari perhitungan diketahui taraf signifikansi $5 \%$ dan $\mathrm{dk}=\mathrm{n}-2$ yaitu $30-2=28$, maka diperoleh $t_{\text {hitung }}>t_{\text {tabel }}$ yaitu 12,932 $>1,697$. Maka $H_{o}$ ditolak dan $\mathrm{H}_{a}$ diterima artinya efektivitas komunikasi yang dilakukan tutor memiliki hubungan dengan motivasi belajar anak usia dini di PKBM Mentari Kayaarta. Berdasarkan perhitungan tersebut, dapat dilihat bahwa terdapat hubungan yang signifikan antara efektivitas komunikasi yang dilakukan tutor dengan motivasi belajar anak usia dini di PAUD PKBM Mentari Kayaarta, Klaten, Jawa Tengah.

\section{SIMPULAN}

Motivasi belajar anak usia dini di PAUD PKBM Mentari Kayaarta, berdasarkan hasil pengolahan data motivasi belajar di daerah berada dalam taraf cukup baik dilihat dari penilaian 4 aspek yaitu tekun dan ulet, minat yang tinggi, mandiri, dan hasrat. Hasil penelitian juga menemukan bahwa terdapat pengaruh efektivitas komunikasi guru terhadap motivasi belajar anak usia dini. Keefektifan komunikasi guru sangat berpengaruh terhadap motivasi belajar anak usia dini, semakin efektif komunikasi guru semakin semangat anak usia dini dalam mengikuti pembelajaran.

\section{UCAPAN TERIMAKASIH}

Terimakasih penulis sampaikan kepada Kepala, admin dan seluruh staf Lembaga PAUD PKBM Mentari Kayaarta Klaten dan yang telah banyak membantu proses penelitian penulis, serta terimakasih kepada tim reviewer dan editor Jurnal Obsesi yang sudah memberikan kesempatan dan membantu perbaikan artikel penulis sehingga siap untuk diterbitkan

\section{DAFTAR PUSTAKA}

Afdilla, T. (2017). Hubungan Antara Dukungan Orang Tua Tunggal (Ibu) dengan Motivasi Belajar pada Siswa di Pondok Pesantren Mawaridussalam. Retrieved from http://repository.uma.ac.id/handle/123456789/8355

Ambarukmi, R. N., \& Wijayanti, D. (2019). Kajian Motivasi Belajar dan Perhatian Orang Tua Terhadap Hasil Belajar Siswa pada Pembelajaran Tematik. In Prosiding Seminar Nasional PGSD UST (Vol. 1). Retrieved from http://www.jurnal.ustjogja.ac.id/index.php/sn-pgsd/article/view/4754

Aulina, C. N. (2018). Penerapan Metode Whole Brain Teaching dalam Meningkatkan Motivasi Belajar Anak Usia Dini. Jurnal Obsesi: Jurnal Pendidikan Anak Usia Dini, 2(1), 112. https:// doi.org/10.31004/obsesi.v2i1.1.

Choiro, U. D., Rasyad, A., \& Supriyono, S. (2018). Keaktifan Belajar Peserta Didik pada Transfer Pengetahuan Kerajinan Pandai Besi. Jurnal Pendidikan: Teori, Penelitian, dan Pengembangan, 3(4), 486-490.

Dwi Julianty, T. (2019). Penanganan Gangguan Komunikasi Pada Anak (Studi Kasus Di Autis Centre Kota Bengkulu). IAIN Bengkulu.

Dwijananti, P., \& Yulianti, D. (2010). Pengembangan kemampuan berpikir kritis mahasiswa 
melalui pembelajaran problem based instruction pada mata kuliah fisika lingkungan. Jurnal Pendidikan Fisika Indonesia, 6(2).

Febrina, N. A., \& Isroah, I. (2012). Peningkatan Aktivitas Belajar Akuntansi Melalui Implementasi Model Pembelajaran Kooperatif Tipe Student Teams Achievement Division (STAD) Pada Siswa Kelas X Ak 3 Program Keahlian Akuntansi SMK Batik Perbaik Purworejo Tahun Ajaran 2011/2012. Jurnal Pendidikan Akuntansi Indonesia, 10(2). https:// doi.org/10.21831/jpai.v10i2.916.

Gunawan, F. (2015). Efektivitas Penggunaan Ashraf \& BCL Sebagai Celebrity Endorser Dalam Iklan Televisi LINE Let's Get Rich Dengan Menggunakan Model TEARS. Jurnal e-Komunikasi, 3(2).

Hardiansyah, S. (2019). Kontribusi Daya Tahan Kekuatan dan Daya Ledak Otot Tungkai terhadap Kemampuan Tendangan Depan Atlet Pencak Silat Unit Kegiatan Olahraga Unp. Jurnal Menssana, 1(2), 61-67. https://doi.org/10.31258/jope.1.1.27-33.

Hermawan, D., \& Kintamani, I. (2015). Kinerja Pendidikan Anak Usia Dini dan Pendidikan Nonformal Berdasarkan Misi Pendidikan. Jurnal Pendidikan Dan Kebudayaan, 21(1), 87-100. https:// doi.org/10.24832/jpnk.v21i1.178.

Hermoyo,P. (2015). Membentuk komunikasi yang efektif pada masa perkembangan anak usia dini. Pedagogi: Jurnal Anak Usia Dini dan Pendidikan Anak Usia Dini, 1 (1).

Muhammad Edra, K. E. N. (2017). Proses Komunikasi Antarpribadi Dalam Mengembangkan Potensi Anak Jalanan (Studi Kasus di Sanggar Alang-Alang Surabaya). Stikosa-AWS.

Munawaroh, H. (2017). Pengembangan Model Pembelajaran dengan Permainan Tradisional Engklek Sebagai Sarana Stimulasi Perkembangan Anak Usia Dini. Jurnal Obsesi: Jurnal Pendidikan Anak Usia Dini, 1(2), 86-96. https:/ / doi.org/10.31004/obsesi.v1i2.19.

Muslimah, N. (2015). Upaya Peningkatan Hasil Belajar Dan Motivasi Siswa Kelas X. 1 Sma Teuku Umar Semarang Melalui Pembelajaran Multiple Intelligences Bervisi Sets. Universitas Negeri Semarang. Retrieved from (Susilo, 2013). Sedangkan menurut Clayton Aldefer (dalam Hamdhu, 2011) motivasi belajar adalah kecenderungan siswa dalam melakukan segala kegiatan belajar yang didorong oleh hasrat untuk mencapai prestasi atau hasil belajar sebaik mungkin.

Nursalam, N., \& Efendi, F. (2008). Pendidikan Dalam Keperawatan Education in Nursing. Salemba Medika. Retrieved from http://eprints.ners.unair.ac.id/534/1/Pendidikan_Dalam_Keperawatan.pdf

Sugiono. (2013). Penelitian Pendidikan. Bandung: Alfabeta.

Sugiyono, P. D. (2010). Metode penelitian pendidikan. Pendekatan Kuantitatif.

Suharsimi, A. (2006). Prosedur penelitian suatu pendekatan praktik. Jakarta: Rineka Cipta.

Sukirman, S. (2011). Peranan Bimbingan Guru dan Motivasi Belajar dalam Rangka Meningkatkan Prestasi Belajar Peserta Didik SMA Negeri 1 Metro Tahun 2010. GUIDENA: Jurnal Ilmu Pendidikan, Psikologi, Bimbingan dan Konseling, 1(1), 23-35. Retrieved from http://ojs.fkip.ummetro.ac.id/index.php/bk/article/view/349. https:// doi.org/10.24127/gdn.v1i1.349.

Susilo, Y. (2013). Peningkatan Motivasi Belajar Siswa Melaluimodel Pembelajaran Kooperatif Tipe Numbered Head Together (Nht) Materi Ajar Perbandingan Dan Fungsi Trigonometri Pada Siswa Kelas X. Mathedunesa, 2(2). Retrieved from https://jurnalmahasiswa.unesa.ac.id/index.php/mathedunesa/article/view/2710

Uce, L. (2017). The golden age: Masa efektif merancang kualitas anak. Bunayya: Jurnal Pendidikan Anak, 1(2), 77-92.

Yuniastuti, E. (2013). Peningkatan keterampilan proses, motivasi, dan hasil belajar biologi dengan strategi pembelajaran inkuiri terbimbing pada siswa kelas VII SMP Kartika V-1 Balikpapan. Jurnal penelitian pendidikan, 13(1). 